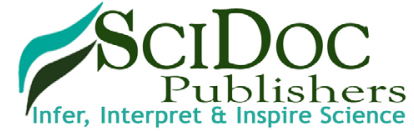

International Journal of Veterinary Health Science \& Research (IJVHSR)

ISSN 2332-2748

\section{Surgical Management of Bumble foot in a cock}

Case Report

Malik Abu Rafee

Division of Surgery, Indian Veterinary Research Institute, India.

\title{
Abstract
}

Bumble foot or plantar pododermatitis, is an inflammatory and typically infected lesion of the plantar aspect of the foot, affecting either the ball of the foot or one or more toes. A case of bumble foot in a 6 year old cock was managed by removal of caseous material with an artery forceps and left open to heal by granulation.

Keywords: Bumble; Pododermatitis; Staphylococcus; Cock.

\section{Introduction}

Bumble foot, also known as plantar pododermatitis, is a condition recognised as an inflammatory and typically infected lesion of the plantar aspect of the foot, affecting either the ball of the foot or one or more toes. It is a common disease of in birds maintained in captivity and tends to become chronic, progressive, and invasive and eventually disabling, which is often unresponsive to medicinal therapy or recur [1]. Bumble foot is characterized by swelling, sometimes redness and often a characteristic black or brown scab on the bottom of the foot. Left untreated, serious cases of bumble foot can be fatal as the infection can spread to other tissues and bones. The organism most commonly implicated in bumble foot is Staphylococcus aureus. This bacteria has a complex pathogenesis, frequently producing endotoxins or exotoxins, which serve as virulence factors [2]. Bumble foot results from injury or abrasion to the lower surface of the foot, which allows the introduction of staphylococcus bacteria, which leads to a pus-filled abscess. The entry point for bacteria can be a cut, scrape, injury or breakdown of the skin from walking on wet, dirty bedding. Lesions can occur on toes, hocks and the pads of the feet [3]. Turk and Stamm [4] reported that the introduction of $\mathrm{S}$. aureus into the skin can initiate a hypersensitization reaction with considerable resultant tissue damage. Hypersensitisation is likely to be an Arthus Type III reaction, which would result in thrombosis and vasculitis [5]. The majority of chronic cases are treated by complete surgical removal of Caseous - accumulation of necrotic debris from the affected tissue.

\section{Case History}

A six year old cock was presented with swelling ball of the foot (Figure 1). History taking revealed that the cock is reared as pet and mostly confined to the cage as there is a threat of attack by stray dogs in the locality of owner. On clinical examination reluctance to walk, lameness and rock hard swelling with a black scab on the pad of paw was observed.

Figure 1. Hard swelling with scab on the pad of paw.

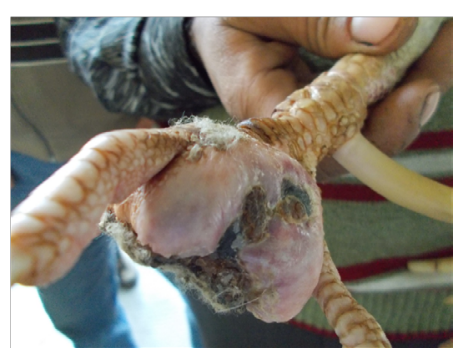

\section{Surgical management}

The skin was vigorously scrubbed with savlon three to four times. It was then painted painted with povidone iodine. The black scab of devitalised tissue on the plantar aspect of the foot was removed gently with the help scalpel blade and artery forceps (Figure 2). This exposed the white gritty necrotic mass/ pus from inside the cavity. All the exposed caseous material was removed carefully. The cavity was flush with hydrogen peroxide

\footnotetext{
*Corresponding Author:

Malik Abu Rafee

Scholar, Division of Surgery Indian Veterinary Research Institute, Izarnagar, UP, India.

E-mail: rafee188@gmail.com
}

Received: April 07, 2016

Accepted: June 28, 2016

Published: June 30, 2016

Citation: Malik Abu Rafee (2016) Surgical Management of Bumble Foot in a Cock. Int J Vet Health Sci Res. 4(5), 130-131. doi: http://dx.doi.org/10.19070/2332-2748-1600027

Copyright: Malik Abu Rafee ${ }^{\circ}$ 2016. This is an open-access article distributed under the terms of the Creative Commons Attribution License, which permits unrestricted use, distribu tion and reproduction in any medium, provided the original author and source are credited. 
to clean out all the pus and debris. All the surrounding tissue was debrided with a scalpel blade. Suturing was not possible in this case and wound was left for healing by granulation. The foot was sufficiently bandaged to pad/cushion the ball of the foot (Figure 3). Antiseptic dressing with povidone iodine and administration of vitamin A was suggested.

Figure 2. Removing of caseous necrotic debris/pus.

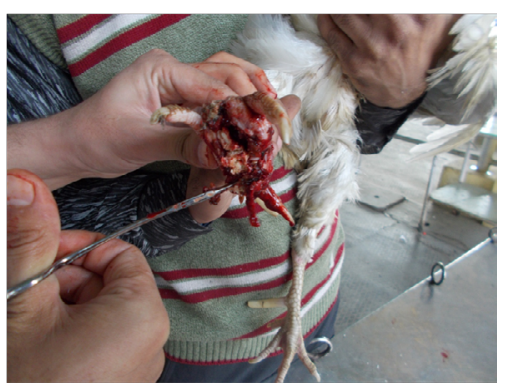

Figure 3. The foot sufficiently bandaged to pad/cushion the ball of the foot.

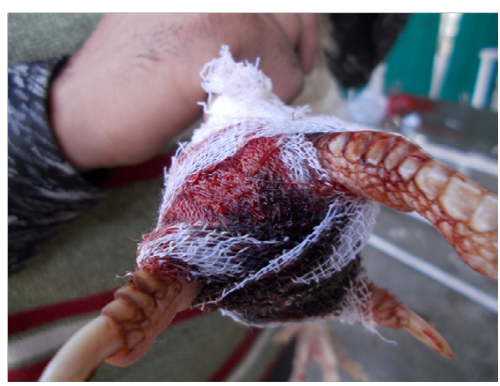

\section{Discussion}

Bumble foot is an infectious and degenerative condition in digital pads and infection can spread into joint and other area in body. Bumble foot is found on the plantar aspect of a bird's feet where it can form an abscess. There are three different but correlated causes for bumblefoot: Unsuitable perches/standing and walking platforms, nutritional deficiency, and infections. These abscesses are frequently caused by inappropriate "perching" conditions, such as plastic perches, sharp-cornered perches, the standard perches that tend to come with cages of a uniform diameter, or wire floors. Treatment and prevention of bumble foot are dependent to progress of conditions. If the swelling is very small and there is no sign of the infection tracking, only appropriate systemic and local antibiotics (mixed with DMSO to helping the penetration of the drugs) and vitamin therapy will be needed [6]. Remple reported that a four pronged therapeutic regime consisting of (1) systemic antibiotic therapy, (2) direct intralesional antibiotic delivery, (3) surgical debridement, and (4) post-operative protective foot casting has offered the most effective therapy for the majority of bumble foot cases [7]. In the vast majority of cases, surgery will be necessary. The aim of surgery was to remove caseous necrotic debris reduce the antigen loading, were possible removing infected and fibrotic tissue in to there by converting a necrotic infected area into a clean, vascular surgical site that can heal [1, 8]. In case of bumble foot surgery stab incision is usually needed, however in the present case the scab over the ulcerated lesion was removed with the help of artery forceps. The puss/necrotic material was gritty in consistency and could be removed with the artery forceps. All the material was removed so as to ensure the nidus free tissue for healing by granulation without recurring. The appearance of healthy granulation tissue around the edges of the wound takes two to five weeks to appear [9].

\section{References}

[1]. Neil AF (2008) Bumble foot surgery and management. Great Western Exotic Vets Unit 10 Berkshire House, County Park, Shrivenham Road, Swindon, SN1 2NR. www.gwexotics.com

[2]. Anderson JC (1986) Staphylococcus. In: Pathogenesis of bacterial infections in animals. ( $1^{\text {st }}$ edn), Iowa State University Press, Ames.14-20.

[3]. Tina Savage. A Fact sheet on Bumble foot.University of Connecticut, USA.

[4]. Turk M, Stamm W (1970) Staphylococcal Infections. In: Harrison's principles of internal medicine. ( $9^{\text {th }}$ edn), Lange Medical Publications. Los Altos, California 608-613

[5]. Remple JD (1993) Raptor Bumble foot: A New Treatment Technique. In: Raptor Biomedicine. University of Minnesota Press. Minneapolis. 154-160.

[6]. Poorbaghi SL, Javdani M, Nazifi S (2012) Surgical treatment of bumble foot in a captive golden eagle (Aquila chrysaetos). Vet Res Forum 3(1): 71-73.

[7]. Remple JD (2006) A multifaceted approach to the treatment of bumble foot in raptors. J Exo Pet Med 15(1): 49-55.

[8]. Coles BH (2007) Essential of avian medicine and surgery. (3edn). London, Blackwell.181-182.

[9]. Petra MB (2010) Symptoms \& Treatment of Bumble foot in Parrots. 